\title{
Modelowanie geostatystyczne osadów dennych zbiornika retencyjnego pod kątem określenia oporności filtracyjnej
}

\author{
Jacek Gurwin ${ }^{1}$, Mikołaj Lotocki ${ }^{1}$
}

\begin{abstract}
Geostatistical modelling of bottom sediments of the retention reservoir in terms of determining filtration resistance. Prz. Geol., 68: 281-286; doi: 10.7306./2020.16

A b s tra c t. In hydrogeological research it is extremely important to skillfully determine the interaction between groundwater and surface water sespecially for determining groundwater resources. It is worth devoting a sufficient attention to obtaining field data of the permeability of riverbed sediments or surface reservoirs bottom sediments. Therefore, having a very good recognition of the bottom sediment lithology for the Turawa reservoir, it was possible to make a spatial model of lithological variability. Finally, 11 lithophases were separated and a $3 D$ model of the sediment block was established. The volumes of individual layers as the total volume and mass of bottom sediments were also calculated.
\end{abstract}

Keywords: lake bottom sediments, geostatistical modelling, retention reservoir

W badaniach hydrogeologicznych, zwłaszcza w celu ustalenia zasobów wód podziemnych, niezwykle ważne jest umiejętne określenie interakcji wód podziemnych z wodami powierzchniowymi. Wykorzystanie nowoczesnych technik geoinformacyjnych umożliwia przygotowanie szerokiego spektrum danych, niezbędnych w numerycznym modelowaniu procesów filtracji wód podziemnych. Zwykle dysponujemy dość dobrym rozpoznaniem w zakresie parametrów poziomów wodonośnych, natomiast nie zawsze wystarczającą uwagę poświęca się na pozyskanie danych terenowych dotyczących przepuszczalności osadów korytowych cieków lub zbiorników powierzchniowych. Takie pomiary można prowadzić skutecznie z wykorzystaniem kolumn infiltracyjnych (Gurwin, Wąsik, 1996), ale wówczas uzyskujemy jedynie dane punktowe i obarczone pewnym marginesem błędu. Poza tym nie w każdych warunkach takie prace są możliwe do przeprowadzenia. W przypadku zbiorników powierzchniowych bardzo rzadko wykonuje się wiercenia lub sondowania w dnie, gdyż są to złożone i kosztowne zabiegi. Dysponując jednak rozpoznaniem litologii osadów dennych zbiornika, można wykonać przestrzenny model zmienności litologicznej i jednoznacznie wskazać obszary o lepszej lub słabszej łączności hydraulicznej z wodami podziemnymi. Obiektem, który został w ramach szeroko zakrojonego projektu badawczego bardzo dokładnie przebadany, także pod względem sedymentologicznym, jest zbiornik Turawa na rzece Mała Panew.

W latach 80. ubiegłego wieku zagadnienia sedymentologiczne zbiornika turawskiego przeanalizował Teisseyre z zespołem (1984), który wskazał, że osady denne tego zbiornika są reprezentowane przez dwa typy utworów głównie muły i piaski, natomiast procesami prowadzącymi do wypełnienia misy jeziora są zamulanie i zapiaszczenie. Znacznie większy zakres prac został podjęty w latach 2002$2004 \mathrm{w}$ ramach interdyscyplinarnego projektu badawczego, obejmującego kompleksowo zagadnienia środowiska gruntowo-wodnego w rejonie sztucznego zbiornika retencyjnego wraz z oceną ekologicznej kondycji tego zbiornika (Gurwin i in., 2004a, b, c). Do przeprowadzenia badań terenowych użyto nowoczesnego sprzętu, łącznie z instalacją automatycznych stacji monitoringu i sieci piezometrów, budową specjalistycznej pływającej platformy wiertniczej, przygotowaniem zestawów próbników i łodzi motorowych. Nigdy do tej pory nie zgromadzono tak dużej bazy różnorodnych, równoczasowych danych środowiskowych w rejonie dużego zbiornika wodnego.

\section{OBSZAR BADAŃ}

Zbiornik retencyjny Turawa znajduje się w południowo-zachodniej Polsce, województwie opolskim, gminie Turawa. Zapora ziemna wraz z zabudowaną elektrownią wodna przecina dolinę Małej Panwi w miejscowości Turawa, ograniczając zbiornik od zachodu. Na południu występują kulminacje terenu nazywane Wzniesieniami Dębskimi. Jest to forma przypominająca wał przebiegający w kierunku wschód-zachód, z rzędną najwyższego punktu 204,9 m n.p.m. Od strony północnej również znajdują się podobne wzniesienia, a rzędna najwyższego punktu wynosi ok. 195 m n.p.m. Na wschodzie zbiornik jest zasilany głównie przez Mała Panew (ryc. 1), ale także przez mniejsze dopływy, jak Libawa i Rosa.

Podłoże geologiczne budują tu skały wszystkich ogniw triasu, należących do monokliny przedsudeckiej, przykryte pokrywą nieskonsolidowanych osadów kenozoiku, głównie wieku plejstoceńskiego i holoceńskiego. Lokalnie występują niewielkie izolowane płaty osadów neogenu, reprezentowane głównie przez iły oraz podrzędnie przez piaski (Trzepla, 1988). Obszary wysoczyznowe są zbudowane przede wszystkim z glin zwałowych zlodowacenia środkowopolskiego. Natomiast czasza zbiornika zalega na piaszczysto-żwirowych osadach aluwialnych powstałych podczas zlodowacenia północnopolskiego. Utwory holoceńskie to piaszczyste osady fluwialne $\mathrm{w}$ pobliżu koryt rzecznych oraz utwory organiczne, tj. namuły i torfy.

$\mathrm{Z}$ punktu widzenia łączności hydraulicznej z wodami zbiornika podstawowe znaczenie mają czwartorzędowe poziomy wodonośne, wydzielone w piaszczysto-żwirowych utworach fluwioglacjalnych wysoczyzn oraz w osadach fluwialnych w dolinie rzecznej. Sa to utwory dobrze przepuszczalne o współczynnikach filtracji od $6 \mathrm{~m} / \mathrm{d}$ do ponad $100 \mathrm{~m} / \mathrm{d}$ (Gurwin $\mathrm{i}$ in., 2005).

\footnotetext{
${ }^{1}$ Zakład Hydrogeologii Stosowanej ING, Uniwersytet Wrocławski, pl. Maxa Borna 9, 50-205 Wrocław; jacek.gurwin@uwr.edu.pl
} 


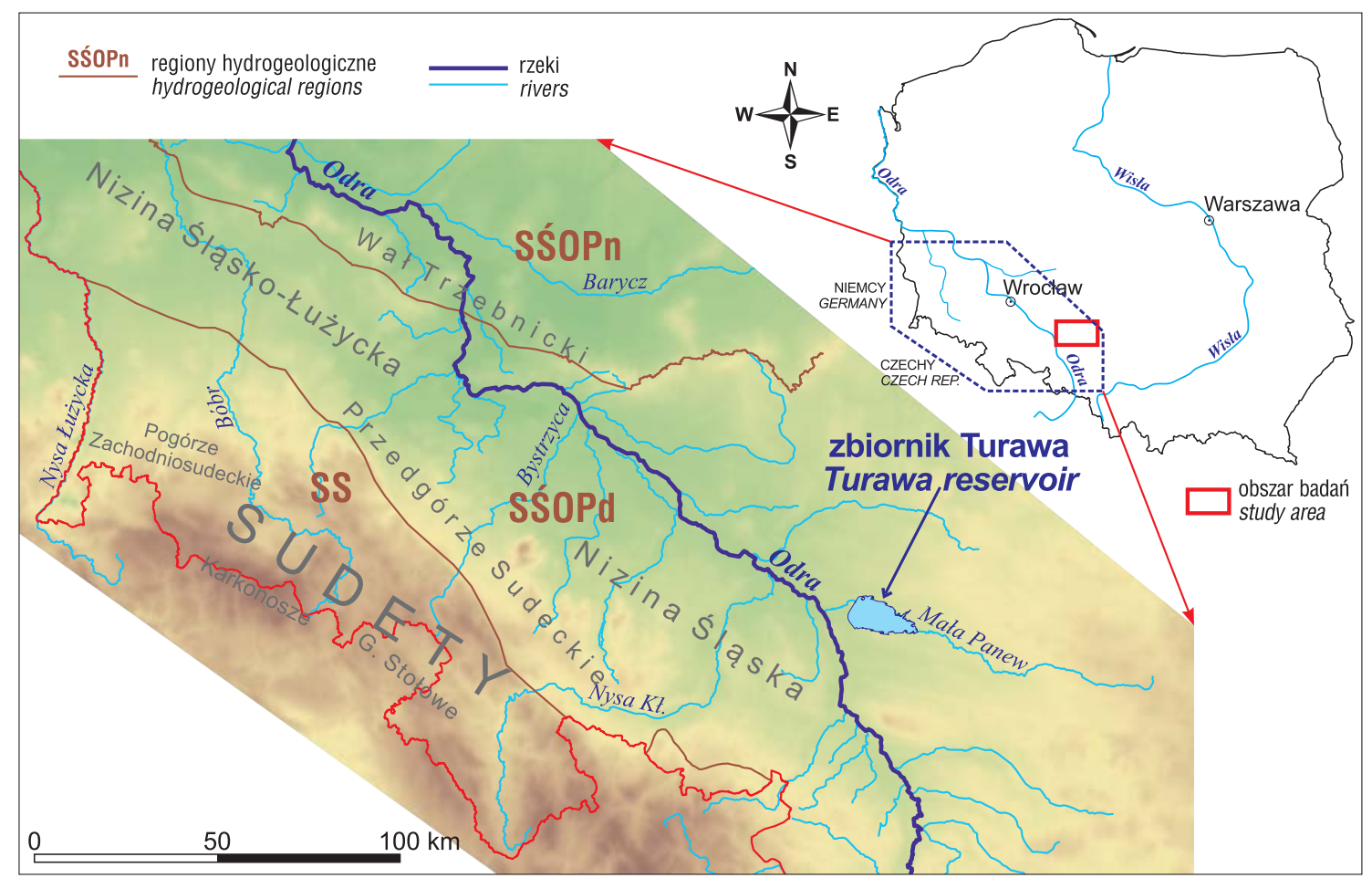

Ryc. 1. Lokalizacja zbiornika Turawa (Gurwin, 2020)

Fig. 1. Location of the Turawa reservoir (Gurwin, 2020)

Zbiornik został oddany do użytku w 1938 r. i w stosunkowo krótkim czasie przekształcił się w jezioro w sensie warunków sedymentacyjnych i geomorfologicznych. Obszar zbiornika przed zalaniem był wykorzystywany jako teren gospodarki leśno-rolniczej, przesiedlono także kilka znajdujących się tam miejscowości.

\section{CEL I METODYKA BADAWCZA}

Celem niniejszej pracy jest przedstawienie możliwości zastosowania metod geostatystycznych i automatycznej interpolacji danych $w$ generowaniu map zasięgu i miąższości poszczególnych wydzieleń litofacjalnych oraz budowy na tej podstawie trójwymiarowego modelu bryły osadów. Obliczenia i modelowanie 3D wykonano w programie Surfer v. 16, z najbardziej zaawansowanymi metodami geostatystycznymi, natomiast moduł do grafiki 3D ma pewne ograniczenia, jak np. brak półprzezroczystych szrafur do lepszej wizualizacji kolejnych warstw. Do analiz wybrano metodę krigingu (Brooker, 1979), jako najlepszą do większości zagadnień z zakresu geologii. Przy czym dołożono starań, aby w każdym przypadku sporządzić optymalny wykres funkcji variogramu i dopasowany do niego model, który $\mathrm{w}$ integracji z krigingiem pozwala uzyskać najbardziej wiarygodny rozkład przestrzenny zmiennej. Zakłada się, że wyniki będzie można w przyszłości wykorzystać do analizy i szczegółowego rozdzielenia warunków oporności filtracyjnej w różnych strefach zbiornika pod kątem symulacji na modelu więzi hydraulicznej między zbiornikiem i wodami podziemnymi.

W ramach projektu zostało wykonanych 85 otworów badawczych - płytkich (do $2 \mathrm{~m}$ ), a także głębszych (nawet $30 \mathrm{~m}$ ), które umożliwiły szczegółową charakterystykę zarówno utworów jeziornych, jak i bezpośrednio podścielających je starszych osadów. Tak gęsta siatka wierceń dała podstawę dla utworzenia bazy danych z profili. Konieczne było przy tym przeliczenie wszystkich danych w m n.p.m., co można było wykonać dokładnie, gdyż w ramach projektu zostały zrealizowane także szczegółowe pomiary batymetryczne. Aktualna konfiguracja dna została odtworzona na modelu po integracji z numerycznym modelem terenu wokół zbiornika (Gurwin i in., 2004a) i była bazą dla przestrzennej interpretacji rozkładu osadów.

\section{PODZIAL I CHARAKTERYSTYKA WYDZIELEŃ LITOFACJALNYCH}

Występujące typy osadów podzielono na grupy o podobnych właściwościach litologicznych, hydrogeologicznych i sedymentacyjnych (tab. 1). Dla przejrzystości analiz, a także z uwagi na niewielką liczbę danych dla efektywnego opracowania każdej z nich osobno, połączono następujące typy:

- otoczaki + żwir i pospółki $=>$ frakcja gruboziarnista o średnim $\phi \geq 2 \mathrm{~cm}$;

- humus piaszczysty + humus gliniasty $=>$ utwory humusowe.

Ostatecznie do dalszych prac przyjęto łącznie 11 litofacji, dla których przeprowadzono analizy rozkładu przestrzennego.

\section{MODEL BRYLY OSADÓW DENNYCH ZBIORNIKA}

Interpretacja osadów dennych w układzie płaskim daje niekompletny obraz, ze względu na nieregularny kształt dna oraz wzajemne ułożenie litofacji. Dlatego dużo wygodniejsze i miarodajne jest stworzenie modelu trójwymiarowego. Głównym założeniem technicznym było utworzenie modelu przestrzennego każdej z litofacji we wspólnym układzie odniesienia. Model przestrzenny powinien być 
Tab. 1. Typy wydzielonych osadów

Table 1. Types of identified sediments

\begin{tabular}{|c|c|c|c|}
\hline \multirow{2}{*}{$\begin{array}{c}\text { Litologia wydzielonej litofacji } \\
\text { Lithology of the identified } \\
\text { lithofacies }\end{array}$} & \multirow{2}{*}{$\begin{array}{c}\text { Opis } \\
\text { Specification }\end{array}$} & \multicolumn{2}{|c|}{$\begin{array}{l}\text { Rodzaje i symbole gruntu wg klasyfikacji } \\
\text { Soil types and symbols acc. to classifications }\end{array}$} \\
\hline & & PN-86/B-02480 & PN-EN ISO 14688-2:2006 \\
\hline $\begin{array}{l}\text { Żwir i pospółki } \\
\text { Gravel and sand-gravels }\end{array}$ & $\begin{array}{l}\text { osady gruboziarniste o uziarnieniu: } \\
\text { coarse-grained deposits: } \\
50 \% \geq \mathrm{f}_{\mathrm{k}}+\mathrm{f}_{\mathrm{z}}>10 \%\end{array}$ & $\begin{array}{l}\dot{\mathrm{Z}}, \dot{\mathrm{Z}}+\mathrm{KO}, \dot{\mathrm{Z}}+\mathrm{Ps}, \mathrm{Po} \\
\mathrm{Po} / / \dot{\mathrm{Z}}\end{array}$ & $\begin{array}{l}\text { Gr, coGr, saGr, grSa, } \\
\text { grSa }\end{array}$ \\
\hline $\begin{array}{l}\text { Piasek gruboziarnisty } \\
\text { Coarse-grained }\end{array}$ & \multirow{4}{*}{$\begin{array}{l}\text { osady drobnoziarniste, niespoiste podzielone ze } \\
\text { względu na procentową zawartość ziarn o danej } \\
\text { średnicy, na podstawie PN-R-04033:1998 } \\
\text { fine-grained, non-coherent deposits divided } \\
\text { by the perceon the basis of acc. to } \\
\text { PN-R-04033:1998 }\end{array}$} & $\mathrm{Pr}, \mathrm{Pr} / \mathrm{Po}, \mathrm{Pr} / \mathrm{Ps}$ & $\mathrm{CSa}$ \\
\hline $\begin{array}{l}\text { Piasek średnioziarnisty } \\
\text { Medium-grained sand }\end{array}$ & & $\mathrm{Ps}, \mathrm{Ps}+\pi, \mathrm{Ps}+\mathrm{KO}, \mathrm{Ps} / \mathrm{Pr}$ & $\mathrm{MSa}, \mathrm{siSa}, \mathrm{coSa}$ \\
\hline $\begin{array}{l}\text { Piasek drobnoziarnisty } \\
\text { Fine-grained sand }\end{array}$ & & $\mathrm{Pd}, \mathrm{Pd} / / \mathrm{G} \pi \mathrm{z}, \mathrm{Pd} / \mathrm{P} \pi$ & FSa, clSa, clsiSa \\
\hline $\begin{array}{l}\text { Piasek pylasty } \\
\text { Silty sand }\end{array}$ & & $\mathrm{P} \pi, \mathrm{P} \pi+\mathrm{Pd}$ & siSa \\
\hline $\begin{array}{l}\text { Piasek humusowy } \\
\text { Humic sand }\end{array}$ & $\begin{array}{l}\text { osady piaszczyste } \mathrm{z} \text { domieszką czesści organicznych } \\
\text { sandy sediments with an admixture of organic parts } \\
\mathrm{I}_{\mathrm{om}}<2 \%\end{array}$ & $\operatorname{Ps}(\mathrm{H})$ & orSa \\
\hline $\begin{array}{l}\text { Utwory gliniasto-pylaste } \\
\text { Clay-silty deposits }\end{array}$ & $\begin{array}{l}\text { osady spoiste pylasto-piaszczyste o zawartości } \\
\mathrm{f}_{\mathrm{i}} \leq 30 \% \text {, sklasyfikowane na podstawie trójkąta Fereta } \\
-\mathrm{PN}-\mathrm{B} / 81-03020 \\
\text { silty-sandy cohesive sediments with fi } \leq 30 \% \\
\text { classified based on the Feret's triangle- } \\
P N-B / 81-03020\end{array}$ & $\begin{array}{l}\mathrm{G} \pi \mathrm{z}, \mathrm{Gpz}, \mathrm{G} \pi \mathrm{z} / / \pi, \mathrm{G} \pi \\
\pi, \pi \mathrm{p}\end{array}$ & siCl, saCl, siCl, Si,saSi \\
\hline $\begin{array}{l}\text { It pylasty } \\
\text { Silty clay }\end{array}$ & $\begin{array}{l}\text { osady ilasto-pylaste o } \mathrm{f}_{\mathrm{i}}>30 \% \\
\text { silty-clayey sediments with } f_{i}>30 \%\end{array}$ & $\mathrm{I} \pi$ & $\mathrm{siCl}$ \\
\hline $\begin{array}{l}\text { Humus piaszczysty } \\
\text { Sandy humus }\end{array}$ & $\begin{array}{l}\text { osady próchnicze piaszczyste } \\
\text { sandy humus sediments }\end{array}$ & $\mathrm{H}(\mathrm{Ps}), \mathrm{H}(\mathrm{Pd}), \mathrm{H}(\mathrm{Ps} / \mathrm{Pd})$ & orSa \\
\hline $\begin{array}{l}\text { Humus gliniasty } \\
\text { Clayey humus }\end{array}$ & $\begin{array}{l}\text { osady próchnicze gliniaste } \\
\text { clayey humus sediments }\end{array}$ & $\mathrm{H}(\mathrm{I} \pi), \mathrm{H}(\mathrm{G} \pi \mathrm{z}), \mathrm{H}(\pi \mathrm{p})$ & orCl \\
\hline $\begin{array}{l}\text { Torf } \\
\text { Peat }\end{array}$ & $\begin{array}{l}\text { osady o zawartości czéści organicznej } \\
\text { sediments containing organic matter } \\
\mathrm{I}_{\mathrm{om}}>30 \%\end{array}$ & $\mathrm{~T}$ & Or \\
\hline $\begin{array}{l}\text { Namuł } \\
\text { Silt }\end{array}$ & $\begin{array}{l}\text { osady o zawartości czéści organicznej } \\
\text { sediments containing organic matter } \\
5 \%<\mathrm{I}_{\mathrm{om}}<30 \%\end{array}$ & $\mathrm{Nm}(\mathrm{Ps}), \mathrm{Nm}(\pi)$ & saOr, siOr \\
\hline
\end{tabular}

bowiem jednolitą warstwą lub zespołem warstw zalegających na odpowiedniej wysokości w m n.p.m. W programie Surfer tworzy się go za pomocą nałożenia stropu i spagu kolejnej warstwy. Rodzi to pewne problemy w związku z licznymi obszarami wyklinowania czy też brakiem danej warstwy. Dlatego pomocne były także mapy rozkładu miąższości osadu, na których widać miejsca gdzie rzeczywiście one występują i jaka jest ich miąższość w danym punkcie.

Jako przykład obliczeń przedstawiono wynikową mapę dla warstwy piasków średnioziarnistych (warstwa C - tab. 2), która jest dominującą składową osadu dennego, występującą powszechnie w obrębie całego obszaru zbiornika. Jej miąższość waha się od kilkucentymetrowych przewarstwień do ponad $7 \mathrm{~m}$ (ryc. 2). Piaski te charakteryzują się stosunkowo wysoką dojrzałością petrograficzną, na co wskazuje dominacja w składzie materiału kwarcowego.

W rzucie od strony południowej (ryc. 3) można zaobserwować dużych rozmiarów nieciagłość w zaleganiu warstwy. Jest ona wypełniona osadami frakcji bardzo drobnoziarnistej i torfami, co może wskazywać na inny charakter sedymentacji na tym obszarze.

Po sporządzeniu wszystkich map dla wydzielonych 11 warstw (symbole od A do K w tabeli 2) przystapiono do ich łączenia na jednej mapie przestrzennej w układzie 3D.

$\mathrm{W}$ tabeli 2 podano skrócone zestawienie przyjętych warstw wraz z symbolem oraz kolorem użytym w bryle osadu 3D na rycinie 4.

Na mapach widoczne jest bardzo duże zróżnicowanie przestrzenne poszczególnych typów osadów (ryc. 4). Frak-
Tab. 2. Zestawienie warstw przyjętych do analizy

Table 2. List of layers accepted for analysis

\begin{tabular}{|l|l|l|}
\hline \multicolumn{1}{|c|}{$\begin{array}{c}\text { Symbol } \\
\text { Symbol }\end{array}$} & \multicolumn{1}{|c|}{$\begin{array}{c}\text { Nazwa } \\
\text { Name }\end{array}$} & \multicolumn{1}{|c|}{$\begin{array}{c}\text { Kolor } \\
\text { Colour }\end{array}$} \\
\hline A & $\begin{array}{l}\text { frakcja gruboziarnista } \\
\text { coarse fraction }\end{array}$ & \\
\hline B & $\begin{array}{l}\text { piasek gruboziarnisty } \\
\text { coarse sand }\end{array}$ & \\
\hline C & $\begin{array}{l}\text { piasek średnioziarnisty } \\
\text { medium-grain sand }\end{array}$ & \\
\hline D & $\begin{array}{l}\text { piasek drobnoziarnisty } \\
\text { fine-grained sand }\end{array}$ & \\
\hline E & $\begin{array}{l}\text { piasek pylasty } \\
\text { silty sand }\end{array}$ & \\
\hline F & $\begin{array}{l}\text { piasek humusowy } \\
\text { humus sand }\end{array}$ & \\
\hline G & $\begin{array}{l}\text { utwory gliniasto-pylaste } \\
\text { clay-silty deposits }\end{array}$ & \\
\hline H & $\begin{array}{l}\text { ił pylasty } \\
\text { silty clay }\end{array}$ \\
\hline I & $\begin{array}{l}\text { utwory humusowe } \\
\text { humus deposits }\end{array}$ \\
\hline J & $\begin{array}{l}\text { torf } \\
\text { peat }\end{array}$ \\
\hline K & $\begin{array}{l}\text { namuł } \\
\text { silt }\end{array}$ \\
\hline
\end{tabular}

cje bardziej drobnoziarniste, jak namuły, iły pylaste, piaski pylaste czy też torfy, występują głównie w zachodniej części zbiornika, a piaski gruboziarniste we wschodniej. Poza warstwą namułów, cały zespół facjalny można uznać za 


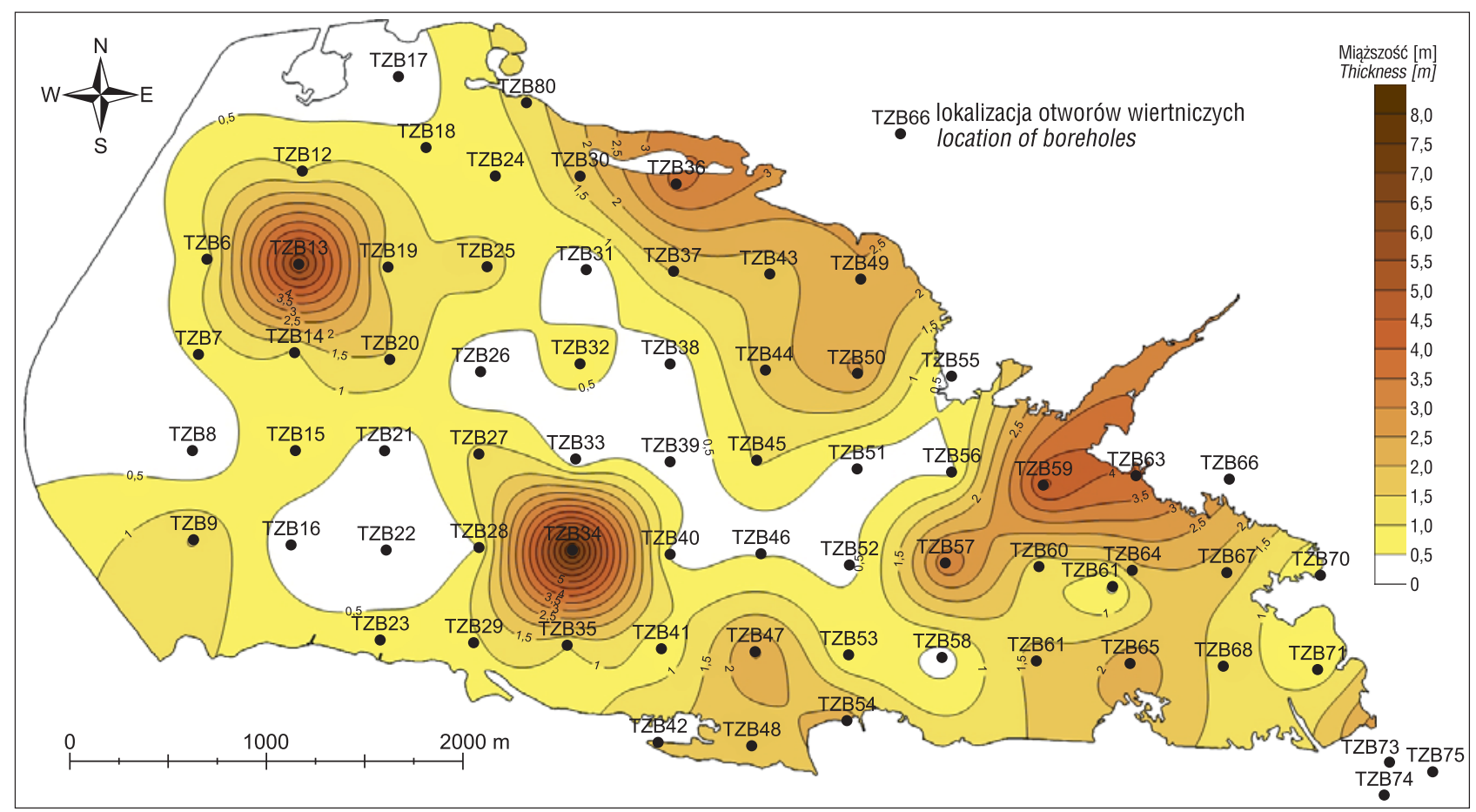

Ryc. 2. Mapa miąższości dla warstwy piasków średnioziarnistych (symbol C - tab. 2)

Fig. 2. Thickness map for the medium-grained sand layer (symbol C - Table 2)

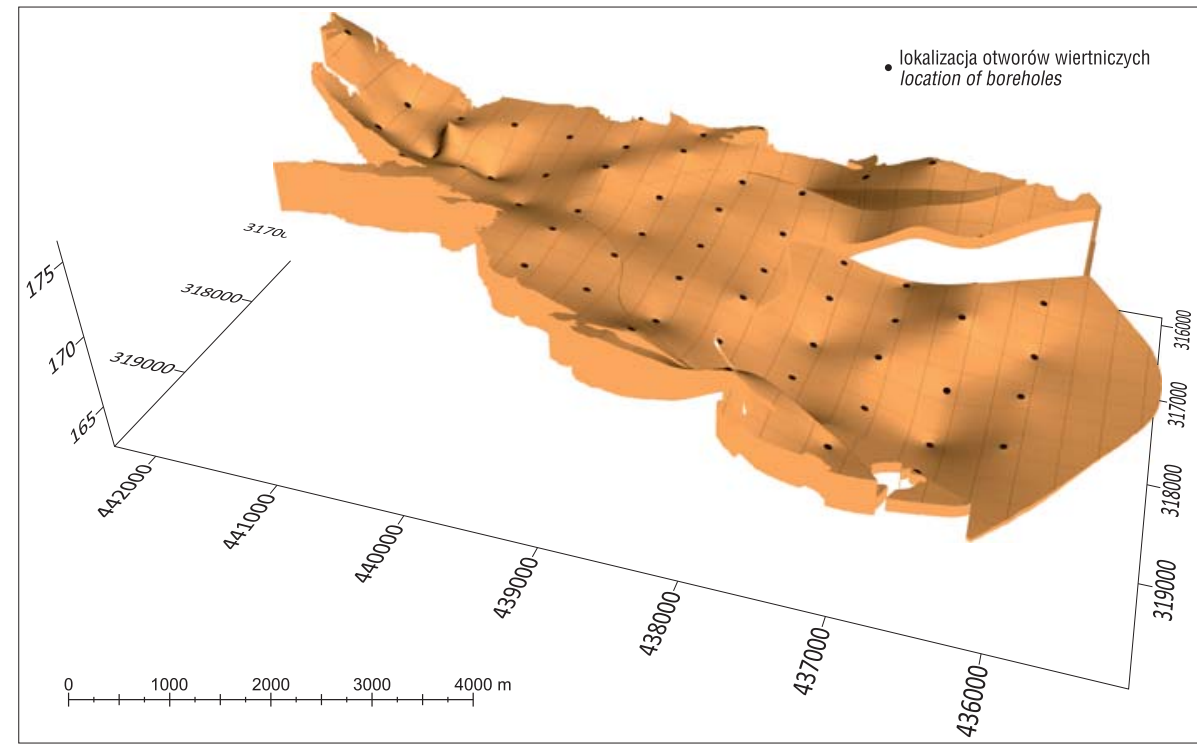

Ryc. 3. Interpretacja warstwy piasków średnioziarnistych w przestrzeni 3D - rzut od południa (symbol C - tab. 2)

Fig. 3. Interpretation of the medium-grained sand layer in a 3D space - projection from the south (symbol C - Table 2)

typowy dla środowiska aluwialnego rzek meandrujących. Ponieważ w ramach projektu zostały wykonane również analizy granulometryczne próbek osadów ze wszystkich otworów zlokalizowanych na obszarze zbiornika, istnieje możliwość oszacowania stosownymi wzorami np. współczynnika filtracji, co będzie pomocne przy określaniu stopnia przepuszczalności całego kompleksu osadów dennych.

$\mathrm{Z}$ uwagi na występowanie bardzo znacznych zawartości zanieczyszczeń w osadach dennych, w tym zwłaszcza metali ciężkich (Gurwin i in., 2004a; Gurwin, 2020), szczególne znaczenie ma warstwa mułów sapropelowych (symbol K), w której zostały zakumulowane najwyższe stężenia różnych składników. Widać wyraźnie, że najwyż- sze miąższości występują w najgłębszej części zachodniej, przy zaporze, gdzie panują najlepsze warunki do gromadzenia się tego typu utworów organicznych w procesie sedymentacji limnicznej. Miąższość zazwyczaj nie przekracza $0,5 \mathrm{~m}$, a maksymalnie osiaga ponad $1,3 \mathrm{~m}$.

Modelowanie geostatystyczne i analizy przestrzenne pozwalaja na bazie wykonanych map 3D przeliczać bardzo ważne wyniki, dotyczące przede wszystkim powierzchni i objętości poszczególnych wydzieleń oraz całkowitej kubatury i masy osadów (tab. 3). Dominujące znaczenie ma warstwa piasków średnioziarnistych, których objętość została określona na $28,9 \mathrm{mln}^{3}$, co stanowi ok. 59\% całości osadów. Średnia miąższość, wynikająca $\mathrm{z}$ podzielenia objętości przez zajmowaną powierzchnię, wynosi $1,73 \mathrm{~m}$. Udział objętości pozostałych wydzielonych warstw waha się w granicach od 1,3 do $7,0 \%$, przy objętościach od $0,65 \mathrm{mln}^{3}$ (frakcje gruboziarniste) do $3,4 \mathrm{mln} \mathrm{m}^{3}$ (utwory humusowe). Warto zauważyć, że objętości najmłodszych osadów, czyli utworów humusowych i namułów, mają bardzo zbliżone wartości i łącznie tworzą znaczącą objętość osadów rzędu $3,5 \mathrm{mln} \mathrm{m}^{3}$, przy średniej miąższości odpowiednio 0,42 i $0,35 \mathrm{~m}$ (tab. 3 ).

Po przyjęciu stosownych gęstości dla poszczególnych typów osadów można było dokonać ostatecznego przeliczenia masy osadu, która w przypadku piasków średnioziarnistych wynosi $57,91 \mathrm{mln} \mathrm{t}$, dla piasków gruboziar- 


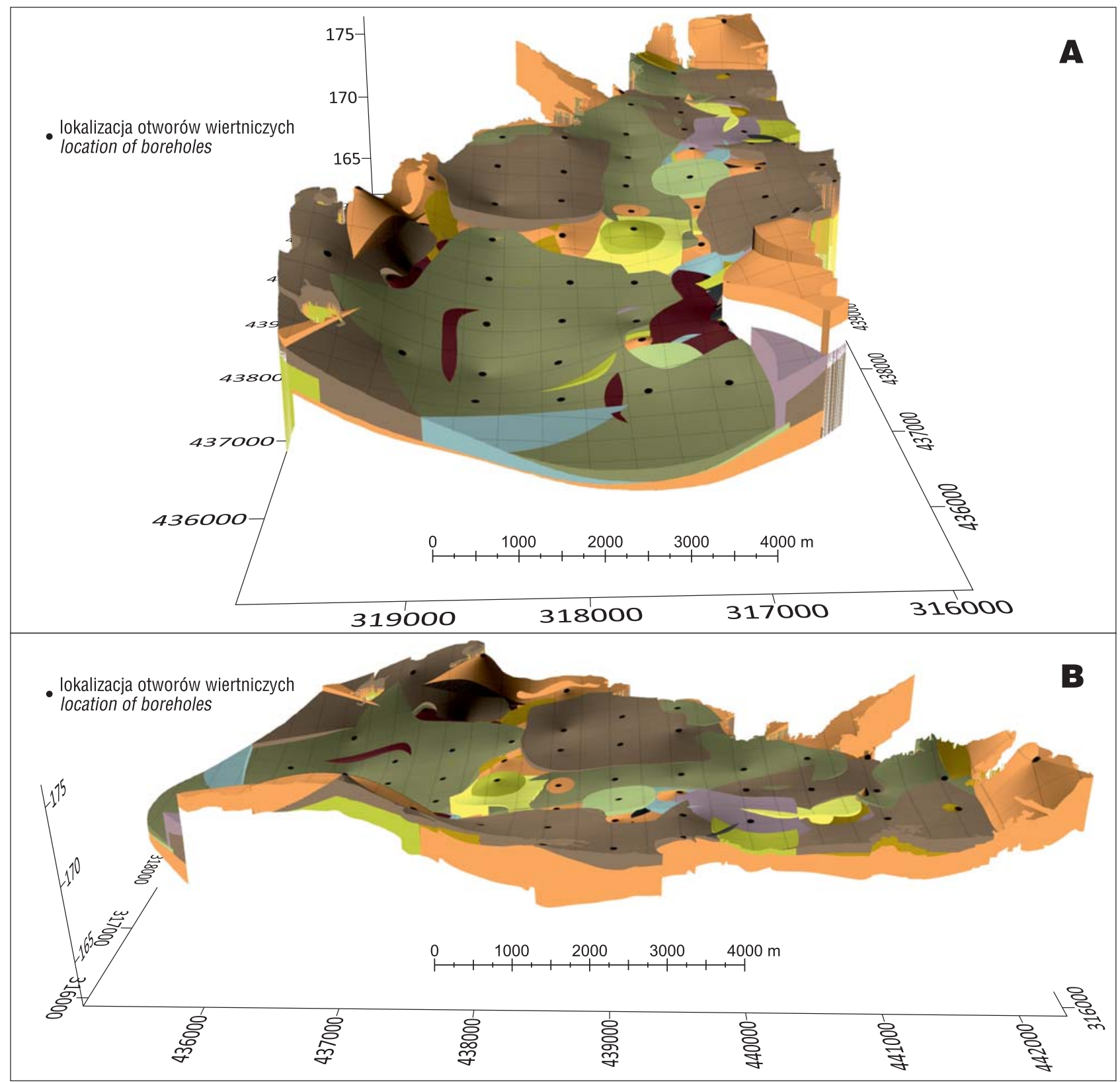

Ryc. 4. Widok trójwymiarowej bryły osadów w kierunku wschodnim (A) i północnym (B)

Fig. 4. Three-dimensional view of the sediment block in the east (A) and north (B) direction

nistych wraz z pozostałą frakcją gruboziarnista, podobnie jak dla piasków drobnoziarnistych, są to wartości wynoszące ok. 5 mln t. Zbliżone wartości określono w przypadku utworów gliniasto-pylastych $(5,21 \mathrm{mln} \mathrm{t})$ i iłów pylastych $(4,72 \mathrm{mln} \mathrm{t})$, a także utworów humusowych $(5,96 \mathrm{mln} \mathrm{t})$ i namułów $(4,52 \mathrm{mln} \mathrm{t})$.

Sumaryczna objętość bryły osadów dennych została obliczona jako równa $48,8 \mathrm{mln}^{3}$, a całkowita masa to 93,3 mln t (tab. 3).

\section{PODSUMOWANIE I WNIOSKI}

Wykorzystanie technik numerycznych, a zwłaszcza modelowania geostatystycznego przy interpretacji rozkładu zmiennych zregionalizowanych, pozwala na wszechstronną analizę danych zebranych z wierceń, w tym przypadku zmienności litofacjalnej osadów dennych zbiornika retencyjnego. Przewaga opracowania trójwymiarowego modelu bryły osadu polega na większej dokładności, szyb- szym i łatwiejszym dostępie do interesujących danych w dowolnym miejscu mapy.

Osady denne zbiornika turawskiego tworzy łącznie 11 zróżnicowanych litofacji, są to głównie osady piaszczyste z przewarstwieniami utworów ilastych, pylastych oraz organicznych. Całkowita objętość bryły osadów dennych została określona na $48,8 \mathrm{mln} \mathrm{m}^{3}$, przy czym blisko $60 \%$ stanowią piaski średnioziarniste. Ustalenie kubatury i typu osadów ma podstawowe znaczenie np. podczas określania ilości i masy materiału, który należy usunąć lub przemieścić na obszarze misy zbiornika, zgodnie z proponowanymi metodami jego rewitalizacji (Gurwin, Skowronek, 2006), czy też przy ustalaniu całkowitej zawartości wybranego składnika zanieczyszczeń w osadach dennych.

Osady zalegające w czaszy zbiornika umożliwiają dobrą wymianę wód powierzchniowych i podziemnych. W świetle dotychczasowych badań hydrogeologicznych stwierdza się intensywną infiltrację do warstw wodo- 


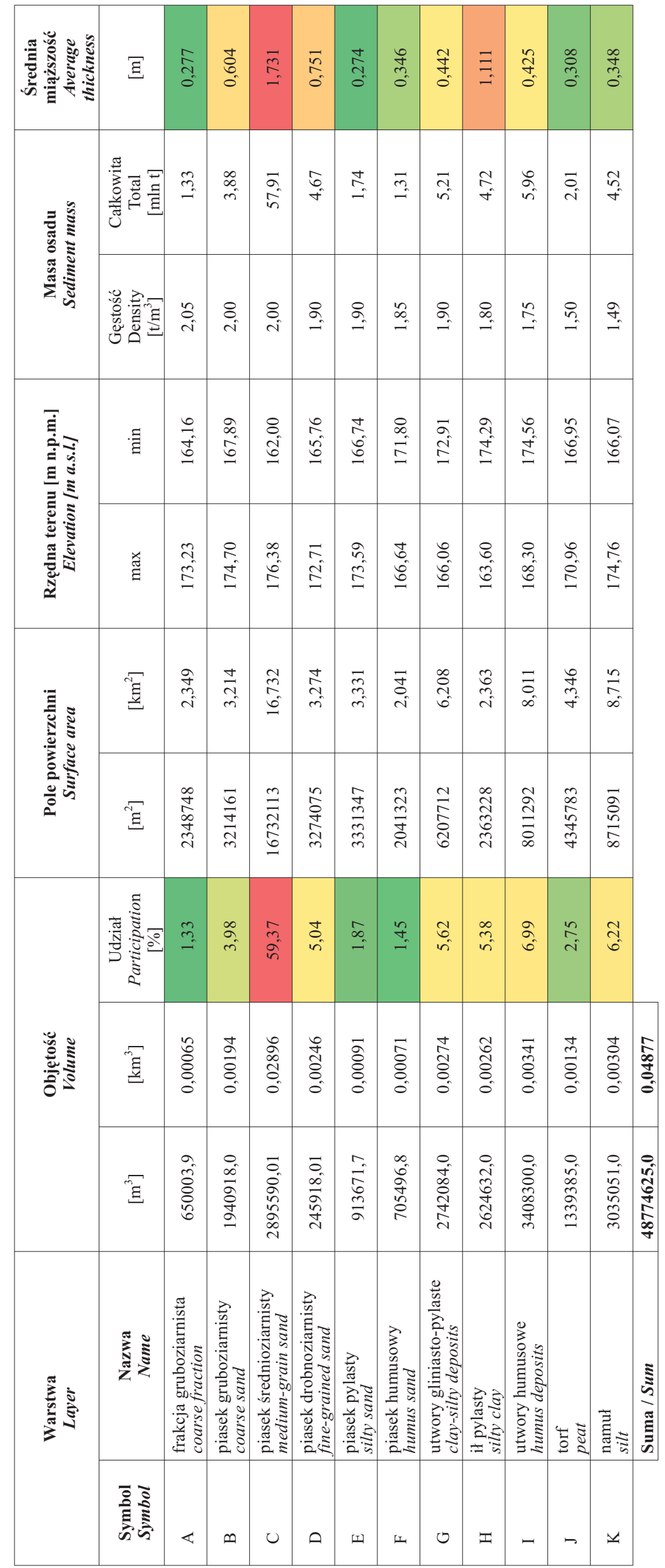

nośnych i na przedpole zapory czołowej. Dlatego w dalszych pracach analiza przestrzennej zmienności różnych typów osadów w połączeniu z oszacowanymi wartościami współczynnika filtracji umożliwi określenie pionowej przepuszczalności, czy też oporności filtracyjnej. Dane te będzie można wykorzystywać w numerycznym modelu filtracji do symulacji przesączania, wprowadzając stosowny warunek brzegowy III rodzaju.

Autorzy pragną podziękować Recenzentom za cenne uwagi, które wpłynęły na ostateczny kształt pracy.

\section{LITERATURA}

BROOKER P. 1979 - Kriging. Eng. Min. J., 180 (9): 148-153.

GURWIN J., KRYZA H., KRYZA J., POPRAWSKI L. 2005 - Rozpoznanie wód podziemnych w rejonie Jeziora Turawskiego dla potrzeb oceny stanu ekologicznego. Współczesne problemy hydrogeologii, t. XII. Wyd. UMK Toruń: 241-253.

GURWIN J. (red.) 2020 - Ocena ekologicznego stanu Jeziora Turawskiego w celu opracowania działań na rzecz jego poprawy. Wyd. ATUT Wrocław (w druku).

GURWIN J. (red.), KRYZA H., KRYZA J., KUROWSKI L., JEDRYSEK M., RACZYŃSKI P., SOLECKI A., SZYNKIEWICZ A. 2004a - Raport końcowy projektu „Ocena stanu ekologicznego Jeziora Turawskiego w celu opracowania działań na rzecz jego poprawy" 2003/2004. UWroc., ING. Wrocław.

GURWIN J., KRYZA J., POPRAWSKI L., SKOWRONEK A. 2004b - Założenia i wstępne wyniki prac badawczych dla oceny stanu ekologicznego zbiornika retencyjnego Turawa i opracowania działań na rzecz jego poprawy. [W:] Problemy ochrony zasobów wodnych w dorzeczu Odry - 2004. Wyd. RZGW, Wrocław: 181-188.

GURWIN J., KRYZA J., POPRAWSKI L., SKOWRONEK A. 2004c - Zintegrowana kampania badawcza dla określenia ekologicznego stanu zbiornika retencyjnego „Jezioro Turawskie" zgodnie z zasadami zrównoważonego rozwoju. Zesz. Nauk. Uniw. Zielonogórskiego nr 131, Inż. Środ., (12): 133-140.

GURWIN J., SKOWRONEK A. 2006 - Koncepcja rewitalizacji zbiornika retencyjnego Turawa - na podstawie „Oceny stanu ekologicznego Jeziora Turawskiego w celu opracowania działań na rzecz jego poprawy". [W:] Problemy ochrony zasobów wodnych w dorzeczu Odry - 2006. Wyd. RZGW, Wrocław: 509-518.

GURWIN J., WASIK M. 1996 - Parametr przesaczania osadów korytowych w badaniach zlewni rzeki Rudnej. Problemy hydrogeologiczne południowo-zachodniej Polski. Dolnoślaskie Wyd. Edukacyjne, Wrocław: 263-270. TEISSEYRE A.K. 1984 - Osady denne Jeziora Turawskiego w świetle badań geologicznych. Geol. Sudet., 18 (1): 21-55.

TRZEPLA M. 1988 - Szczegółowa Mapa Geologiczna Polski, ark. Jełowa. Wyd. Państw. Inst. Geol., Warszawa. 